\title{
HOLTHUISEA, A NEW GENUS FROM THE EOCENE OF ITALY (DECAPODA, BRACHYURA, HEXAPODIDAE)
}

\author{
BY \\ DANIÈLE GUINOT ${ }^{1,4}$ ), ANTONIO DE ANGELI ${ }^{2,5}$ ) and \\ ALESSANDRO GARASSINO $^{3,6}$ ), \\ $\left.{ }^{1}\right)$ Muséum national d'Histoire naturelle, Département Milieux et Peuplements aquatiques, \\ 61 rue Buffon, CP 53, F-75253 Paris Cedex 05, France \\ 2 ) Piazzetta Nostro Tetto 9, I-36100 Vicenza, Italy; Museo Civico 'G. Zannato', \\ Piazza Marconi 15, I-36075 Montecchio Maggiore, Vicenza, Italy \\ 3 ) Museo di Storia Naturale di Milano, Corso Venezia 55, I-20121 Milano, Italy
}

\begin{abstract}
A middle Eocene (Lutetian) species from Italy placed in the extant genus Stevea Manning \& Holthuis, 1981, and described as S. cesarii Beschin, Busulini, De Angeli \& Tessier, 1994, should in fact be assigned to a related but distinct genus, here named Holthuisea gen. nov. Newly collected, well-preserved material of $H$. cesarii allows to supplement previous descriptions. Comparisons of Holthuisea with known fossil and extant genera of the Hexapodidae, in particular with Stevea williamsi (Glassell, 1938) from the eastern tropical Pacific, are provided. A re-examination of the holotype of $S$. williamsi from Guatemala shows that it is not a male but a female, while a female specimen from Mexico that was assigned to $S$. williamsi by Schweitzer \& Feldmann (2001) turns out to be Paeduma cylindraceum (Bell, 1859), a species which was previously known exclusively from the male holotype. Some comments on the abdominal holding structures of the Hexapodidae are provided.
\end{abstract}

\section{RÉSUMÉ}

L'espèce fossile de l'Eocène moyen (Lutétien) d'Italie rapportée au genre actuel Stevea Manning \& Holthuis, 1981, et décrite sous le nom de S. cesarii Beschin, Busulini, De Angeli \& Tessier, 1994, doit être en fait attribuée à un genre proche mais distinct, nommé ici Holthuisea gen. nov. Un matériel nouveau et bien conservé d' $H$. cesarii permet de compléter les descriptions antérieures. Une comparaison d'Holthuisea avec tous les genres connus fossiles et actuels d'Hexapodidae, et en particulier avec Stevea williamsi (Glassell, 1938) du Pacifique

\footnotetext{
$\left.{ }^{4}\right)$ Corresponding author; e-mail: guinot@mnhn.fr

5 ) e-mail: antonio.deangeli@alice.it

6) e-mail: alegarassino@gmail.com 
oriental tropical, est présentée. Un nouvel examen de l'holotype de S. williamsi du Guatemala montre qu'il s'agit d'une femelle et non d'un mâle, tandis qu'un spécimen femelle du Mexique identifié à S. williamsi par Schweitzer \& Feldmann (2001) s'avère être Paeduma cylindraceum (Bell, 1859), espèce jusqu'à présent connue exclusivement par le mâle holotype. Quelques observations sur les structures pour le maintien de l'abdomen chez les Hexapodidae sont ajoutées.

\section{INTRODUCTION}

The relatively small family Hexapodidae, which comprises both extinct and modern species, is easily recognized by the thoracic sternum with subparallel and similarly developed sternites 5-7 and a reduced sternite 8 (not 7 sternites only, as erroneously noted by Schweitzer \& Feldmann, 2001, table 1), as well as by the suppression of the last pereiopod at the exception of a vestigial coxa, the possession of a peculiar mechanism between carapace and cephalothorax, the dorsal location of the first abdominal somite, often completely covered by the carapace and concealed, the particular abdominal locking mechanism, and the frequent presence of a stridulatory apparatus and of sternal trenches sheltering the first gonopods which protrude from the sterno-abdominal cavity (Barnard, 1950: 299-301, fig. 56d-1; Monod, 1956: 361-374, figs. 471-502; Gordon, 1971: 106, figs. 1-3; Guinot, 1979: 114, 115, 215, figs. 32, 33E-F; 2006: 553-571, figs. 1-4; Schweitzer \& Feldmann, 2001: 330-338, 344-345, figs. 2-4, tables 1, 2; Ng et al., 2008: 86, figs. 77, 78; Guinot, Tavares \& Castro, in preparation). In their important revision, Manning \& Holthuis (1981: 166181, figs. 31-40) described several new hexapodid genera amongst which was Stevea Manning \& Holthuis, 1981, represented by a single living species, $S$. williamsi (Glassell, 1938, as Hexapus). The purpose of the present paper is to show that a species from the Eocene of Italy described as Stevea cesarii by Beschin et al. (1994) in fact belongs to a distinct genus, described here as Holthuisea gen. nov.

\section{MATERIAL AND METHODS}

Measurements of carapace length $\times$ carapace width are given in millimetres $(\mathrm{mm})$, respectively. Abbreviations used are as follows: cl: carapace length; cw: carapace width; mxp3: external maxillipeds; wo-f: width of orbito-frontal margin. MCZ: Museo Civico 'G. Zannato', Montecchio Maggiore, Vicenza, Italy; MSNM: Museo di Storia Naturale di Milano, Milano, Italy; MNHN: 
Muséum national d'Histoire naturelle, Paris, France; OUMNH: Zoological Collections, Oxford University Museum of Natural History, Oxford, England; SDSNH: San Diego Museum of Natural History, San Diego, California, U.S.A.; USNM: National Museum of Natural History, Smithsonian Institution, Washington, D.C., U.S.A.

Terminology. - In several hexapodid genera, the sterno-abdominal cavity (termed "fossa" by Gordon, 1971: 109, and Manning \& Holthuis, 1981: 169, or "trench" by Manning, 1982: 160) is hollowed on each side of its anterior portion by a lateral extension, which is here referred to as "sternal trench" (instead of "groove" as in Tesch, 1918: 241; Gordon, 1971: 108; Manning \& Holthuis, 1981: 168; Manning, 1982: 160; Huang et al., 2002: 658; Schweitzer \& Feldmann, 2001: 335; Guinot, 2006: 556; or "sillon sternal" as in Monod, 1956: 363). These sternal trenches shelter the distal portions of the male first gonopods which protrude from the sterno-abdominal cavity in some genera, i.e. they are not covered by the abdomen and partially protected only by dense cover of setae (Gordon, 1971: 108, fig. 3; Guinot, 1979: 163, 167, fig. 33; Huang et al., 2002: 658, fig. 4A). In fossil specimens, comparable sternal trenches are not easily observed because the anterior half of the ventral surface of the thoracic sternum is not or poorly preserved.

\section{SYSTEMATIC ACCOUNT}

\section{EUBRACHYURA Saint Laurent, 1980}

HeTEROTREMATA Guinot, 1977

Family HeXAPODIDAE Miers, 1886

Genus Stevea Manning \& Holthuis, 1981

Stevea Manning \& Holthuis, 1981: 168, 177.

Stevea - Schweitzer \& Feldmann, 2001 (pro parte): 337, 345 (key); Huang et al., 2003: 653, table 1 (list); Guinot, 2006: 560; Ng et al., 2008: 86 (list).

Not Stevea - Beschin et al., 1994: 191; 2009: 78; Schweitzer et al., 2000: 55; Schweitzer \& Feldmann, 2005: 35; Schweitzer, 2005: 289; De Grave et al., 2009: 33.

Type species. - Hexapus williamsi Glassell, 1938, by original designation. Species included. - Only the type species, extant, Stevea williamsi (Glassell, 1938).

Diagnosis (female). - Carapace $1 / 3$ wider than long, subrectangular; posterolateral borders short, slightly convex; anterolateral borders converging anteriorly, passing below exorbital angle. Dorsal surface convex longitudinally; 
cervical and branchio-cardiac grooves present, faint; 2 round branchio-cardiac depressions. Front depressed, with concave border, widening distally. Eyes movable, cornea narrower than stalk. Mxp3 broad; endopod: ischium mesially expanded, merus flattened, carpus, propodus, dactylus slender, subcylindrical; exopod with flagellum. Female abdomen long, narrow; somite 1 free, somites 2-6 fused, with sutures still distinct on lateral sides, somite 5 with straight lateral margins, somite 6 long, narrow, subhexagonal. Stridulatory apparatus consisting of row of close-set striae. Sternal trenches absent. Chelipeds unequal, propodus of major cheliped large. Other pereopods short.

Remarks. - The above diagnosis is modified from Manning \& Holthuis (1981) as they had based this on a female individual. In particular, the abdominal condition described with fused somites 2-6 and the sutures being barely visible (only medially), albeit still distinct on the lateral sides (see below), is actually valid only for the female.

Stevea williamsi (Glassell, 1938), the type and only species thus far known in the genus, is apparently a rare species. The holotype, $5.8 \times 8.6 \mathrm{~mm}$, from San José, Guatemala (SDSNH 3940, ex 1158), is a female, not a male as indicated by Glassell (1938: 445), as shown by the ventral surface of the abdomen which has biramous pleopods (fig. 1D). This error was not noted by Manning \& Holthuis (1981) or by Guinot (2006). The only other known specimen that has been referred to this species, a female from Mexico (USNM 170897), turns out to be Paeduma cylindraceum instead (see below).

\section{Stevea williamsi (Glassell, 1938)}

(fig. 1A-D)

Hexapus williamsi Glassell, 1938: 445, pl. 35 figs. 1-4.

Hexapus williamsoni - Stephensen, 1946: 182 (incorrect spelling).

Stevea williamsi - Manning \& Holthuis, 1981: 177, fig. 8.

Hexapus williamsi - Hendrickx, 1995: 139 (list).

Stevea williamsi - Schweitzer \& Feldmann, 2001 (pro parte): 337, 345 (key); Huang et al., 2003: 653, table 1 (list); Guinot, 2006: 562, fig. 3; Ng et al., 2008: 86 (list).

Not Stevea williamsi — Beschin et al., 1994: 192; 2009: 78; Schweitzer et al., 2000: 55;

Schweitzer \& Feldmann, 2005: 35; Schweitzer, 2005: 289; De Grave et al., 2009: 33.

Remarks. - Thanks to a re-examination and new photographs of the holotype of Hexapus williamsi (SDSNH 3940) provided to us by L.L. Lovell and D. Cadien, we can now safely state that it is a female, rather than a male as was indicated by Glassell (1938: 446). Because they did not study the holotype, neither Manning \& Holthuis (1981: 177) nor Guinot (2006: 563) noted this error. Consequently, descriptions of the abdomen of $S$. williamsi by Glassell 
(1938: 445, pl. 35 fig. 4), Manning \& Holthuis (1981: 168, 177) and Guinot (2006: 562, fig. 3B, C) all concern that of a female. The holotype is a smallsized individual, $8.6 \mathrm{~mm} \mathrm{cw}$, with a narrow abdomen, non-setose pleopods, and still indistinct gonopores (L.L. Lovell, pers. comm. 2009), all features indicative of a subadult female. The previous (2005) report by L.L. Lovell in Guinot (2006: 562) of "first gonopods [... essentially straight, with only a slight distal curvature" for $S$. williamsi actually refers to the female pleopods instead of the gonopods. Several new illustrations of this female holotype, kindly provided by L.L. Lovell, are included here (fig. 1A-D).

The female abdomen of the holotype consists of six somites plus the telson, but only somite 1 is free, as is the telson; somites 2-6 are fused, with the sutures still distinct on the lateral sides (in dorsal and ventral views), yet barely visible medially (fig. 1B, C; L.L. Lovell and D. Cadien, pers. comm. 2009); somites 2-5 are approximately of equal length; somite 6 is very long.

Stevea williamsi is known exclusively from Guatemala, the type locality, the record from the west coast of Mexico by Schweitzer \& Feldmann (2001) being incorrect (see below).

The identity of 'Stevea williamsi' from Mexico. - The supposed record of 'Stevea williamsi' from Mexico by Schweitzer \& Feldmann (2001) requires discussion. A female specimen, $9.4 \times 14.4 \mathrm{~mm}$ (USNM 170897), from the Gulf of Tehuantepec, west coast of Mexico, identified as Stevea williamsi by R.B. Manning and never illustrated, belongs to different species and genus. Schweitzer \& Feldmann (2001: 337), who examined this specimen in an attempt to redefine the genus Stevea, did not realise that the identification was wrong. Guinot (2006: 562) pointed out that the identification of the Mexican specimen was doubtful and suspected that it "may well prove to belong to Paeduma". This suspicion is now confirmed with the help of photographs kindly provided by Rafael Lemaitre. The Mexican female is in fact Paeduma cylindraceum (Bell, 1859), a species which was so far exclusively known by the holotype, a male $(15.3 \times 23.5 \mathrm{~mm})$, from the Pacific coast of central America (OUMNH). The Mexican specimen shows all the typical features of Paeduma, in particular: carapace wide, with a pitted surface; frontal margin concave; mxp3 operculiform, endopod with broad ischium and merus, slender propodus, carpus and dactylus, cylindrical palp, and dactylus extending only two-thirds of ischium; well visible apodemal platelets on the coxae of the pereopods; exposed portion of sternite 8 showing as an oblique, ornamented plate inserted between sternite 7 and abdominal somite 1 . The adult female of $P$. cylindraceum has a long abdomen, with all 


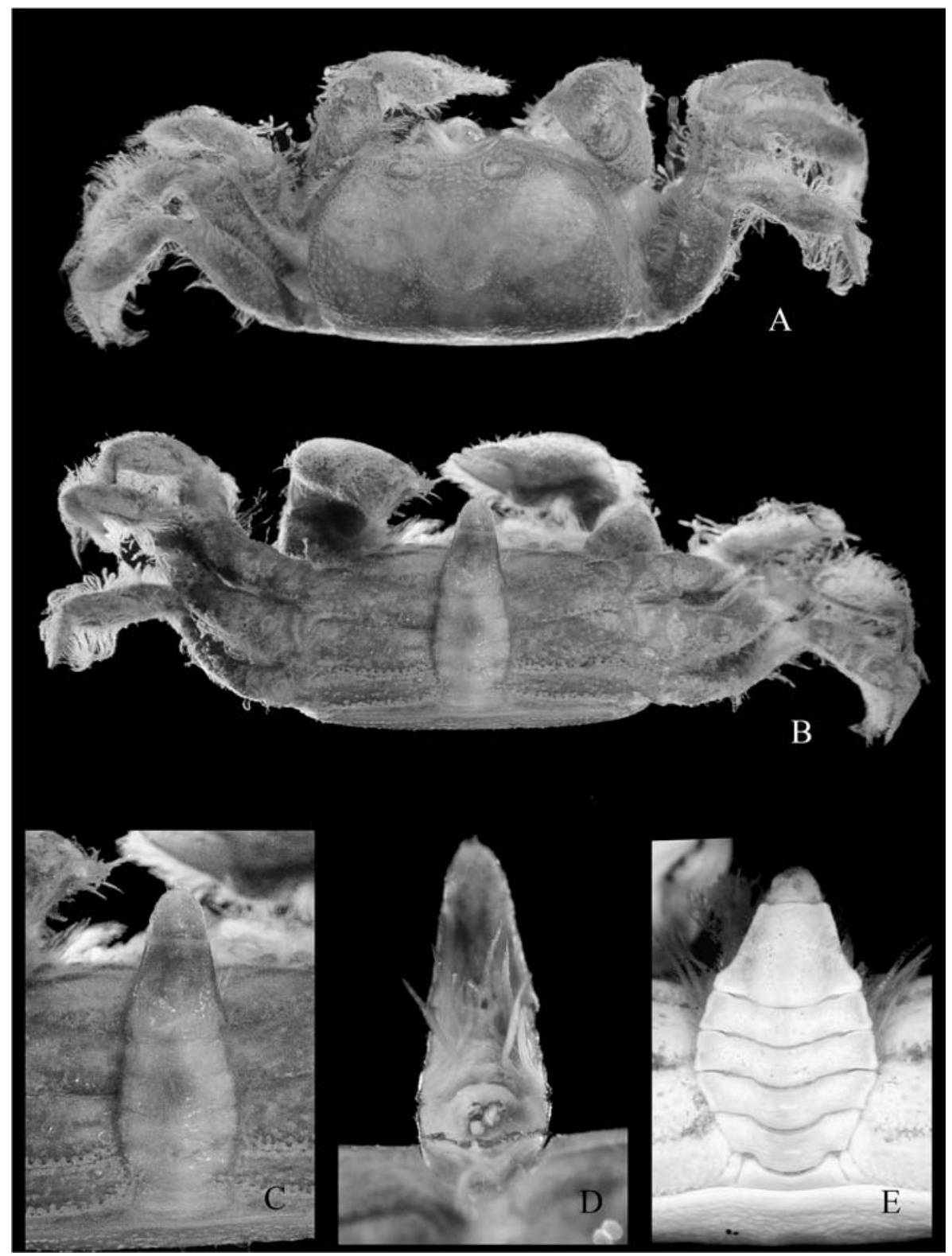

Fig. 1. A-D, Stevea williamsi (Glassell, 1938), female, holotype, $5.8 \times 8.6 \mathrm{~mm}$, San José, Guatemala (SDSNH 3940): A, dorsal view; B, ventral view; C-D, dorsal (C) and ventral (D) views of the abdomen, with somites 2-6 fused. E, Paeduma cylindraceum (Bell, 1859), female, $9.4 \times 14.4 \mathrm{~mm}$, Gulf of Tehuantepec, west coast of Mexico, R.B. Manning det. Stevea williamsi (USNM 170897): abdomen with all somites free. (A-D, photographs by L.L. Lovell; E, by R. Lemaitre.) 
somites distinctly free (fig. 1E) (in contrast to the fused abdominal somites 3-5 of the male, Guinot, 2006, figs. 1B, 2B, E), somite 1 very narrow, somites 2-4 progressively widening, somite 5 narrower, somite 6 much elongated and markedly tapering from a wide base to a broadly triangular telson. The inflated latero-anterior angles of abdominal somite 6 correspond to the sockets of the well visible locking "buttons", persistent in the adult female, which is a trait of the Hexapodidae (Guinot \& Bouchard, 1998, fig. 17E; Guinot \& Quenette, 2005: 334, fig. 29B). The dry condition of the holotype male did not allow Guinot (2006) to examine the abdominal locking system: the narrowness of the sterno-abdominal cavity and of somite 6 leaves only little room for the location of pairs of buttons and sockets, respectively, surely close to one another.

\section{Genus Holthuisea gen. nov.}

Stevea - Schweitzer et al., 2000 (pro parte): 55; Schweitzer \& Feldmann, 2001 (pro parte): 337, 345 (key); 2005: 35 (as Stevia, incorrect spelling); Schweitzer, 2005 (pro parte): 289; De Grave et al., 2009 (pro parte): 33.

Not Stevea — Beschin et al., 1994: 191, fig. 8, pl. 10 figs. 1, 3-5; 2009: 76, pl. 4 figs. 5-7.

Type species. - Stevea cesarii Beschin, Busulini, De Angeli \& Tessier, 1994, by present designation.

Included species - Only the type species. Gender: feminine.

Etymology. - It is both an honour and a pleasure to dedicate this new genus to the late Lipke B. Holthuis in recognition of his considerable contribution to scientific knowledge and of his exceptional personality.

Diagnosis. - Carapace wider than long, subrectangular; posterolateral borders subparallel, then regularly converging anteriorly and reaching exorbital angle. Dorsal surface convex longitudinally, cervical and branchio-cardiac grooves absent; only 2 deep, round branchio-cardiac depressions. Front depressed, extending beyond orbits, widened distally; margin straight in front view. Orbits elongated, supraorbital border rounded, rimmed. Eyes relatively large, not reduced. Mxp3 (present in MCZ 3000-I.G.336821; figs. 2C, 4B) somewhat pediform, slender, inclined; endopod: ischium short, mesially expanded; merus narrow, inclined; carpus short; propodus subcylindrical; dactylus lanceolate. Thoracic sternum with punctate surface. Sutures $4 / 5$ to $6 / 7$ equidistant; sternites 1 and 2 advanced between mxp3; sternite 3 well distinct, demarcated by suture; sternite 4 well developed, with latero-anterior projections; sternites 5-7 inflated, approximately of same size; sternite 7 tilted, with its posterolateral corner (episternite 7) forming marked projection which fits 

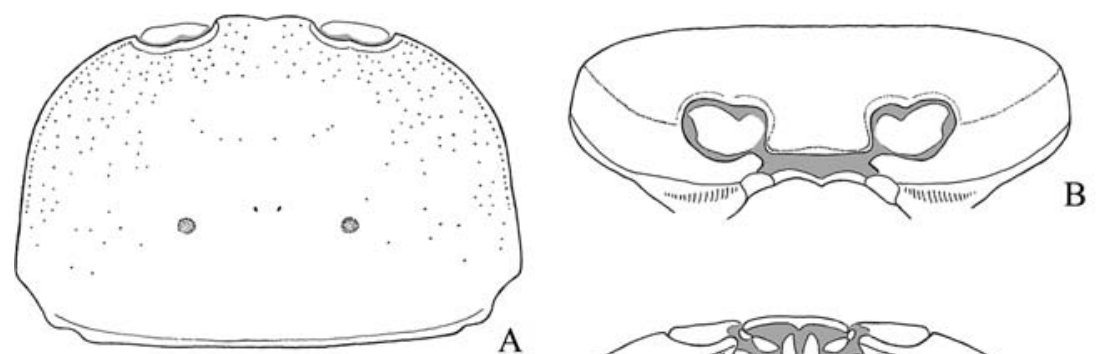

A
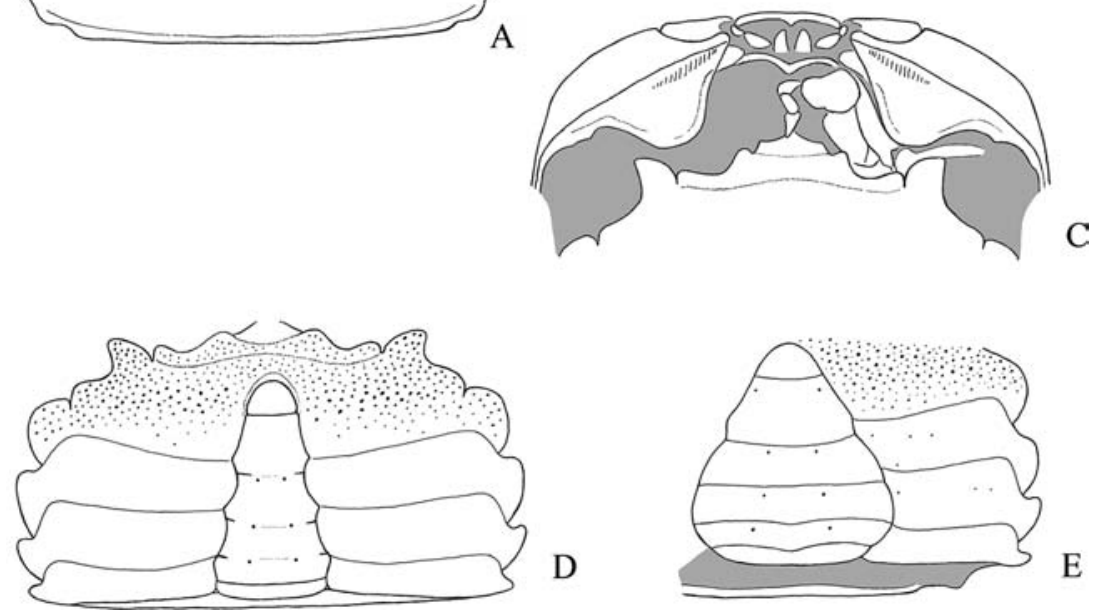

$\mathrm{D}$

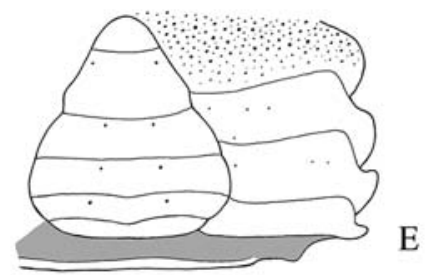

Fig. 2. Holthuisea cesarii (Beschin, Busulini, De Angeli \& Tessier, 1994) comb. nov. AD, male, $5.8 \times 9.3 \mathrm{~mm}$ (MCZ 3000-I.G.336821): A, dorsal carapace; B, frontal view (see stridulating crest); $\mathrm{C}$, anterior ventral view; D, abdomen with somites 3-6 fused. E, female, paratype, cl $7.8 \mathrm{~mm}$ (MCZ 1454-I.G.286328), abdomen with somites 1-6 free.

into notch on carapace margin (interlocking mechanism carapace/sternum). Sternite 8 barely visible, exposed part obsolete. Male abdomen relatively wide, long, somites 1 and 2 free; suture 2/3 well marked; somites 3-6 fused, forming a continuous plate, but with sutures $3 / 4,4 / 5,5 / 6$ indicated laterally by vestigial lines marked by pair of pits; somites 3 and 4 subrectangular, equal in size; somite 5 subtrapezoidal, with concave margins; somite 6 wider than long, subtrapezoidal. Female abdomen with all somites and telson free; sutures well distinct, lined by pair of pits; somite 1 present but most part hidden by carapace, somites 2 and 3 progressively widened, somites 4-6 progressively less wide and higher, 6 being large, telson small. Stridulatory apparatus consisting of raised, triangular area with a row of close-set, unequal striae, 14 in number (fig. 2B, C). Absence of sternal trenches in both sexes. Chelipeds: propodus smooth, with only small pits. 
Holthuisea cesarii (Beschin, Busulini, De Angeli \& Tessier, 1994) comb. nov. (figs. 2-4)

Stevea cesarii Beschin, Busulini, De Angeli \& Tessier, 1994: 192, fig. 8, pl. 10 figs. 1, 3-5 (not fig. 2).

Stevea cesarii - Schweitzer et al., 2000 (pro parte): 55; Schweitzer \& Feldmann, 2001 (pro parte): 337, 345 (key); De Angeli \& Beschin, 2001: 38; Beschin \& De Angeli, 2004: 21; Schweitzer, 2005 (pro parte): 289; De Angeli \& Garassino, 2006: 67. Stevea cesarii? - Guinot, 2006: 567.

Material examined. - 18 specimens from the middle Eocene of "Albanello" quarry at Nogarole Vicentino, Vicenza, northeast Italy. Holotype, male, $5.9 \times 8.1 \mathrm{~mm}$, wo-f $4.5 \mathrm{~mm}$ (MCZ 1452-I.G.286326). Paratypes, 1 carapace, $5.8 \times 9.2 \mathrm{~mm}$, wo-f $4.8 \mathrm{~mm}$ (MCZ 1176I.G.211691); 1 carapace, $5.6 \times 8.2 \mathrm{~mm}$, wo-f $4.8 \mathrm{~mm}$ (MCZ 1431-I.G.284619); 1 carapace, $6.9 \times 10.7 \mathrm{~mm}$, wo-f $5.9 \mathrm{~mm}$ (MCZ 1451-I.G.286325); $1 \mathrm{male}, 5.1 \times 8.0 \mathrm{~mm}$, wo-f $4.4 \mathrm{~mm}$ (MCZ 1453-I.G.286327); 1 female, cl 7.8 mm (MCZ 1454-I.G.286328).

Other material. - Male, $5.8 \times 9.3 \mathrm{~mm}$, wo-f $5.1 \mathrm{~mm}$ (MCZ 3000-I.G.336821); male, cw $7.4 \mathrm{~mm}$, wo-f $4.1 \mathrm{~mm}$ (MCZ 3001-I.G.336822); carapace, $5.3 \times 8.2 \mathrm{~mm}$, wo-f $4.6 \mathrm{~mm}$ (MSNM i27411); carapace, $4.7 \times 7.0 \mathrm{~mm}$, wo-f $3.7 \mathrm{~mm}$ (MSNM i27412); carapace, $4.4 \times 6.4 \mathrm{~mm}$, wo-f $3.6 \mathrm{~mm}$ (MSNM i27413); carapace, $4.5 \times 6.4 \mathrm{~mm}$, wo-f $3.7 \mathrm{~mm}$ (MSNM i27414); carapace, cw $5.7 \mathrm{~mm}$ (MSNM i27415); carapace, cw $7.8 \mathrm{~mm}$ (MSNM i27416); carapace, $7.5 \times 10.5 \mathrm{~mm}$, wo-f $5.8 \mathrm{~mm}$ (MSNM i27417); male, $5.0 \times 7.9 \mathrm{~mm}$, wo-f $4.4 \mathrm{~mm}$ (MSNM i27418); carapace, cw $8.8 \mathrm{~mm}$ (MSNM i27419); carapace, cw $10 \mathrm{~mm}$ (MSNM i27420); carapace, cw $6.3 \mathrm{~mm}$ (MSNM i27421).

Remarks. - The most closely related genus to Holthuisea gen. nov. would be Stevea Manning \& Holthuis, 1981, the type species and only known extant species of which, Stevea williamsi, is recorded only from the American Pacific coast (Guatemala). The middle Eocene (Lutetian) taxon originally identified $S$. cesarii by Beschin et al. (1994: 192, fig. 8, pl. 10 fig. 1, 3-5) requires its own genus, Holthuisea gen. nov. which is established here. Beschin et al. (1994) considered the abdominal somites 2-6 to be fused in the fossil male holotype by erroneously counting somite 2 as somite 1 . We are actually of the opinion that the abdominal somite 1 is concealed under the carapace, the somite 2 free, and somites 3-6 are fused, with still distinct lateral sutures (fig. 3B). Newly collected fossil material (figs. 2D, 4B-D) confirms this identification of the abdominal somites (see Material examined). Evidently, the recognition of the first abdominal somite and/or which fused abdominal somites are actually fused is sometimes difficult even in extant species. This is even more difficult in fossils, especially when the sutures are faint or absent (see $\mathrm{Ng}$ et al., 2008: 14).

Holthuisea (male and female known) shares some features with Stevea (only female known), notably in the general outline of the carapace; presence of two 


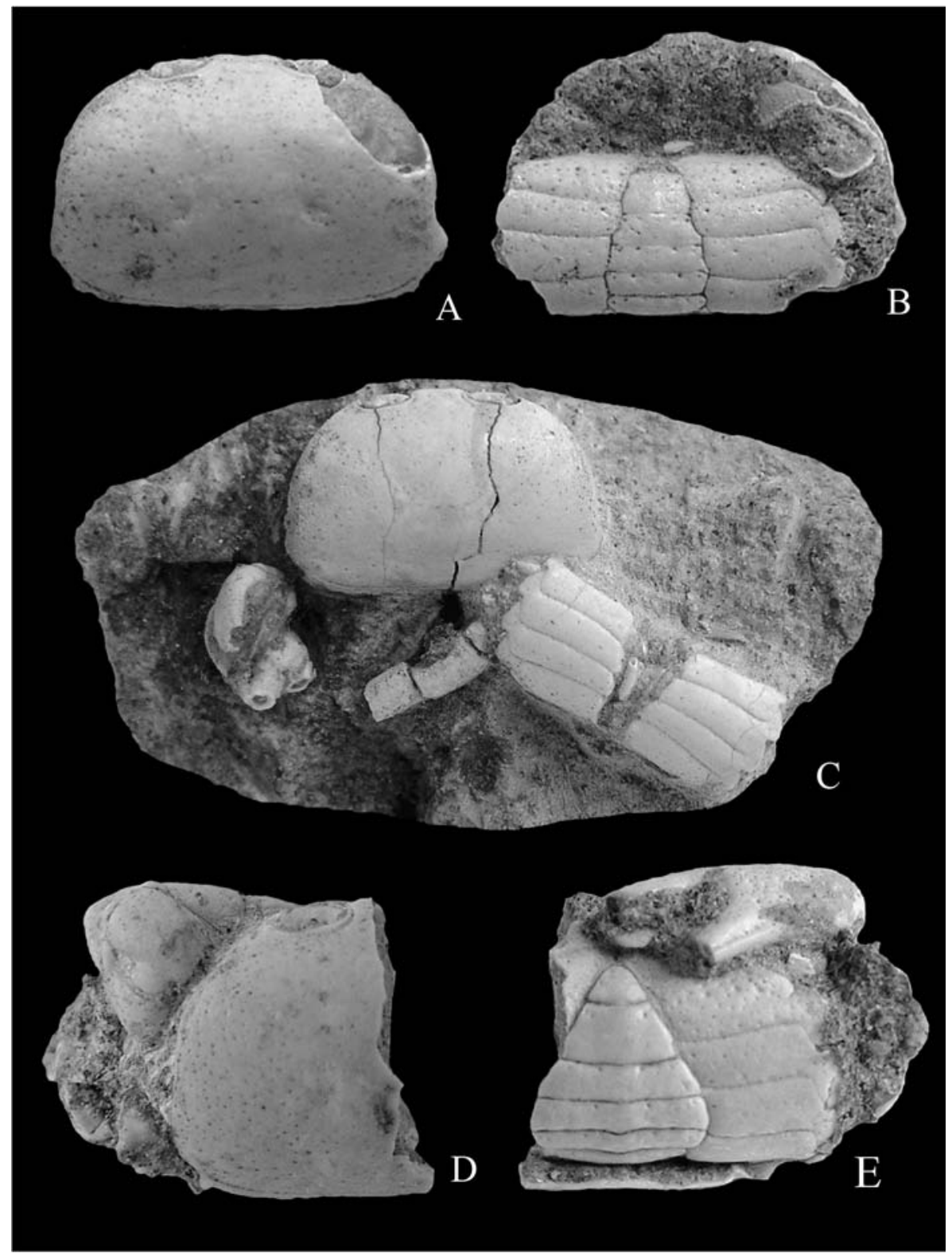

Fig. 3. Holthuisea cesarii (Beschin, Busulini, De Angeli \& Tessier, 1994) comb. nov.: A, B, holotype, male, $5.9 \times 8.1 \mathrm{~mm}$, "Albanello" quarry at Nogarole Vicentino, Vicenza (MCZ 1452I.G.286326): dorsal and ventral views, see abdomen with somites 3-6 fused. C, paratype, male $16.9 \times 0.7 \mathrm{~mm}$, same origin (MCZ 1451-I.G.286325): dorsal and ventral parts dislocated $(\times 3.8)$. D, E, paratype, female, cl $7.8 \mathrm{~mm}$, same origin (MCZ 1454-I.G.286328): dorsal and ventral views, see abdomen with all somites free. 
deep, round branchio-cardiac depressions; presence of a stridulatory apparatus as a row of striae; thoracic sternite 8 obsolete; absence of sternal trenches; and the fusion of several abdominal somites.

Characters distinguishing Holthuisea from Stevea are as follows: anterolateral border joining the exorbital angle in Holthuisea (passing below the exorbital angle in Stevea), resulting in a different curvature of the anterior portion of the anterolateral border; cervical and branchio-cardiac grooves absent in Holthuisea (figs. 2A, 3A, C, 4A) (present in Stevea, fig. 1A; see also Guinot, 2006, fig. 3A); front straight in Holthuisea (figs. 2A-C, 3A, 4A, E) (concave, with median protuberance in Stevea, fig. 1A); orbits relatively more elongated, with supraorbital border more rounded and elongated, in Holthuisea; and the eyes proportionately larger in Holthuisea (narrow, cylindrical in Stevea).

A comparison of the female abdomen of Holthuisea (male and female known) and that of Stevea (only known by the small female holotype) is significant in revealing that in female Holthuisea (figs. 2E, 3E) all the abdominal somites are free, with the sutures clearly distinct, lined by two pits; somites 4-6 are progressively higher and less wide; somite 6 is large; and the telson is short and small. The female abdomen of $S$. williamsi (fig. 1B-D; see also Guinot, 2006, fig. 3B, C) has somites 2-6 fused, immobile, with sutures $2 / 3$ to $5 / 6$ still distinct laterally but noticeable medially, and lacking pits, somites 3 and 4 approximately equal in size, somite 5 with straight margins, somite 6 longer than wide, elongated, narrow, subhexagonal, and the telson elongated.

The wide male abdomen of Holthuisea (figs. 2D, 3B, 4B-D) has somites 1 and 2 free, somites 3-6 fused, with the suture $2 / 3$ well marked but sutures $3 / 4,4 / 5$, and $5 / 6$ indicated laterally by vestigial lines and marked by one pit on each side; somites 3 and 4 are subrectangular, equal in size, somite 5 is subtrapezoidal, with most part of its margins concave, somite 6 is wider than long, and the telson is short and narrow, subovate. Holthuisea is characterised by all abdominal somites free in the female (figs. 2E, 3E) and somites 3-6 fused in the male. In contrast, female Stevea (fig. 1B-D) has somites 2-6 fused, a condition which suggests that the somites could be similarly fused in the male, for now unknown.

Holthuisea is similar to extant Paeduma Rathbun, 1897 in showing a wide carapace, with pitted surface, two deep branchio-cardiac depressions on the dorsal surface, a concave frontal margin, operculiform mxp3, fusion of several abdominal somites, presence of stridulatory apparatus, and the absence of sternal trench. The most important difference concerns the shape of the male 


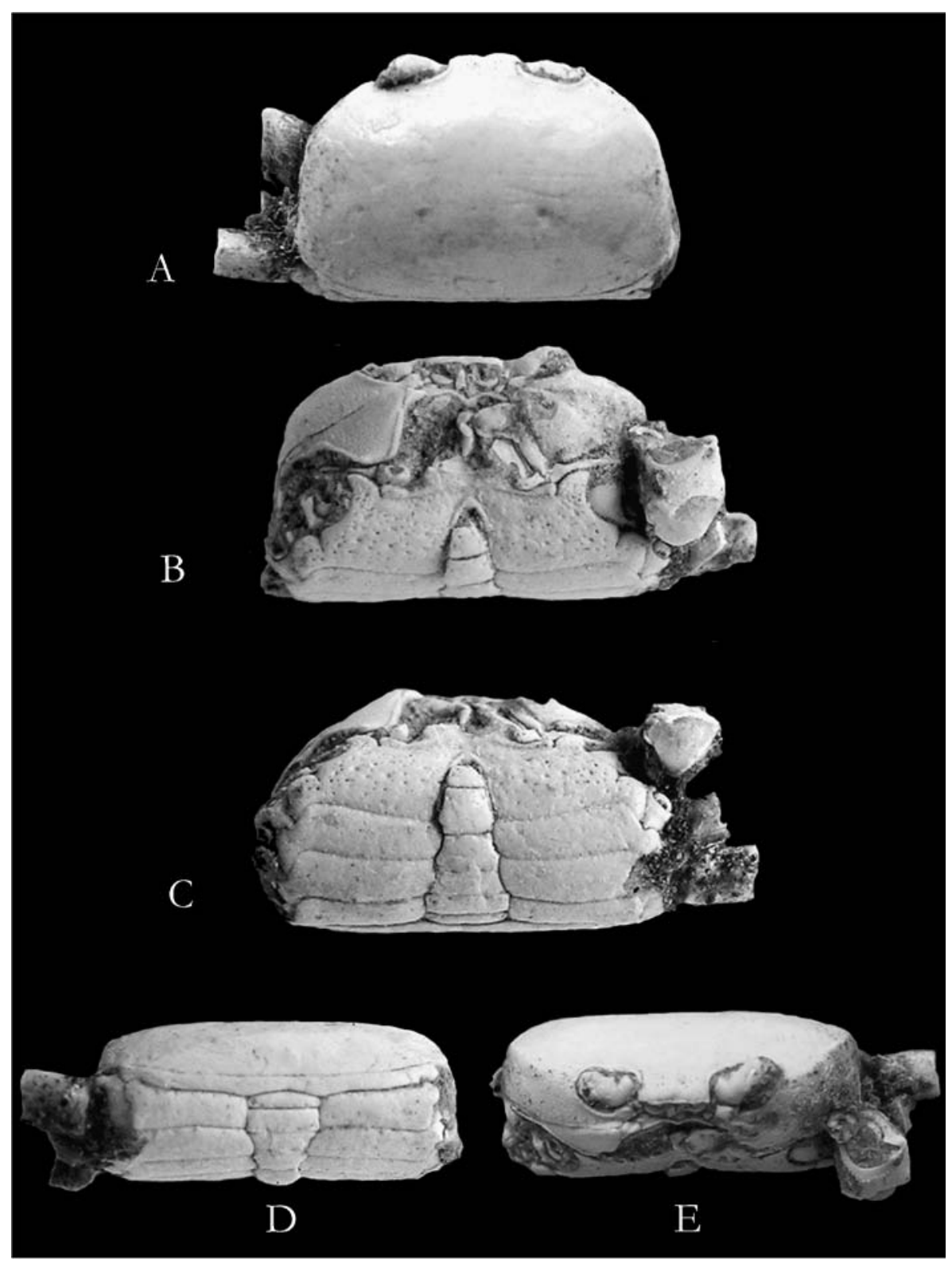

Fig. 4. Holthuisea cesarii (Beschin, Busulini, De Angeli \& Tessier, 1994) comb. nov., male $5.8 \times 9.3 \mathrm{~mm}$, "Albanello" quarry at Nogarole Vicentino, Vicenza (MCZ 3000-I.G. 336821). A, dorsal view; B, ventral anterior view; C, thoracic sternum and abdomen with somites 3-6 fused; $\mathrm{D}$, posterior view; $\mathrm{E}$, frontal view. 
abdomen: relatively wide, with somites 3-6 fused and somite 6 wider than long in $H$. cesarii (figs. 2D, 3B, 4B-D), instead of narrow, with somites 3-5 fused and somite 6 extremely elongated in $P$. cylindraceum. In females of both $H$. cesarii (figs. 2E, 3E) and P. cylindraceum (fig. 1E) all the abdominal somites are similarly free, but the abdomen, mainly somite 6 , is proportionately longer in P. cylindraceum.

\section{COMPARISON OF HOLTHUISEA GEN. NOV. WITH FOSSIL GENERA}

Bellhexapus De Angeli, Guinot \& Garassino, 2010 (type species, by original designation: B. granulatus De Angeli, Guinot \& Garassino, 2010), from the middle Eocene of Italy, differs from Holthuisea by many characters, chiefly: outline of carapace, moderately wider than long; granular ornament on entire carapace and thoracic sternum surfaces; orbits large and round; eyes reniform; low number (8) of well-spaced striae in stridulatory apparatus; strong curvature of thoracic sternum; male abdomen longer, most of somites free, separated by distinct sutures, somites 2 and 3 supposedly fused, showing as a subrectangular, undivided plate, somite 6 well developed, subquadrate, with conspicuous subproximal process. See De Angeli et al. (2010, figs. 2, 3).

Eohexapus De Angeli, Guinot \& Garassino, 2010 (type species, by original designation: E. albertii De Angeli, Guinot \& Garassino, 2010), from the middle Eocene of Italy, differs from Holthuisea as follows: carapace wider, more rectangular, widening anteriorly; lateral margins curved and converging posteriorly; cervical and branchio-cardiac grooves absent, only two deep, round branchio-cardiac depressions; orbits small and rounded; front bilobate; female abdomen with somite 1 hidden by carapace, somites 2-6 free; abdominal somites 4-6 progressively less wide and higher; propodus of chelipeds with granulations. Male abdomen unknown. See De Angeli et al. (2010, figs. 4-6).

Eurohexapus De Angeli, Guinot \& Garassino, 2010 (type species, by original designation: E. lobatus De Angeli, Guinot \& Garassino, 2010), from the middle Eocene of Italy, differs from Holthuisea chiefly by: carapace as long as wide, subquadrate; dorsal carapace surface undulate, with regions defined by protuberances; cardiac region large, inflated; epibranchial lobe salient; numerous conspicuous depressions on gastric region; orbits enormous; rostrum much elongated and deflected; male abdominal somites 2-6 fused, all sutures well distinct; presence of three ventral protuberances, one on abdominal somite 6 and one on each side of sternite 4. See De Angeli et al. (2010, figs. 7-9). 
Goniocypoda Woodward, 1867 (type species, by monotypy: G. edwardsi Woodward, 1867) differs from Holthuisea as follows: carapace wider, more rectangular; probable presence of a branchio-cardiac groove; front very narrow; orbits more elongate; eyes long and narrow. In the diagnosis of Goniocypoda provided by Schweitzer \& Feldmann (2001: 335), their indication of variously fused abdominal somites (either 3-5 or 5 and 6), despite the difficulty in distinguishing sutures, leads us to assume that this genus is not monophyletic and may need a re-appraisal. See also Schweitzer (2005: 290).

Hexapus De Haan, 1833 (type species, by subsequent designation of the International Commission of Zoological Nomenclature: Cancer sexpes Fabricius, 1798), comprises about five extant species ( $\mathrm{Ng}$ et al., 2008: 86) and five fossil ones. As diagnosed by its type species $H$. sexpes (see Manning \& Holthuis, 1981: 169, 171; Manning, 1982: 157, figs. 1, 2), Hexapus is differentiated by: carapace more dilated posteriorly, then distinctly sloping ventrally; lateral margin as a raised tuberculate ridge (Manning, 1982, fig. 1a) (not a granular ridge, as in Holthuisea); front weakly extended, sinuous and medially emarginate (Manning, 1982, fig. 1b) (weakly extended and straight in Holthuisea); orbits smaller and more rounded; eyes much more reduced; male abdomen narrow, somites 3-5 fused (Manning, 1982, fig. 1f) (abdomen wide, somites 3-6 fused in Holthuisea); stridulatory apparatus on a large, oblique, flat area with several long, oblique striae, i.e. approximately four elongated, five short and alternate, plus distally a few, short additional ones (Manning, 1982, fig. 1b) (a row of subequal, short striae, 14 in number, in Holthuisea); presence of deep sternal trenches, either rather short and curved in Hexapus sexpes (see Manning, 1982, fig. 1b) or extending almost to bases of mxp3 in H. anfractus (Rathbun, 1909). See Manning \& Holthuis (1981, fig. 33b).

Palaeopinnixa Via Boada, 1966 (type species, by original designation: P. rathbunae Schweitzer, Feldmann, Tucker \& Berglund, 2000; originally Pinnixa eocenica Rathbun, 1926, see Schweitzer et al., 2000) differs in having: regions of dorsal surface obviously indicated, cervical and branchio-cardiac grooves marked; front extending well beyond orbits; supraorbital margin markedly sinuous; male abdominal somites 3-5 fused in the type species. See Schweitzer et al. (2000: 56, figs. 15-17).

Globihexapus Schweitzer \& Feldmann, 2001 (type species, by monotypy: G. paxillus Schweitzer \& Feldmann, 2001) was removed to the Pinnotheridae De Haan, 1833 (Nyborg, 2002; Schweitzer, 2005) and to the Varunidae in the Asthenognathinae Stimpson, 1858 (De Grave et al., 2009: 45). 


\section{COMPARISON OF HOLTHUISEA GEN. NOV. WITH EXTANT GENERA}

Hexalaughlia Guinot, 2006 (type species, by original designation: Thaumastoplax orientalis Rathbun, 1909) differs from Holthuisea in having: dorsal carapace with a faint $\mathrm{H}$-shaped median groove and without two lateral branchio-cardiac depressions; gastric region may be sharply outlined; anterolateral margin straighter over almost entire length; eyes small; mxp3 slender, inclined, gaping; endopod with short, mesially expanded ischium; merus narrow, inclined; propodus as long as broad, considerably dilated and with mesial expansion distally; dactylus lanceolate, with long setae entering sternoabdominal cavity; small exposed portion of sternite 8 more clearly visible; male abdomen very long, extending beyond bases of mxp3, narrow, with somites 3-5 fused in undivided and anteriorly narrowing plate, somite 6 showing as a long plate; absence of stridulatory apparatus. See Rathbun (1910: 346, fig. 33, pl. 2 fig. 1) and Guinot (2006: 562, fig. 4).

Hexapinus Manning \& Holthuis, 1981 (type species, by monotypy: Hexapus latipes De Haan, 1835) differs from Holthuisea in having: the front which is obscurely divided into two straight-edged lobes by a shallow median depression; absence of lateral branchio-cardiac depressions on carapace dorsal surface; eyes more reduced; male abdominal somites 3-5 fused (Campbell \& Stephenson, 1970, fig. 49; Manning \& Holthuis, 1981, figs. 31, 32c); only a few but long, unequal stridulatory striae distributed obliquely over a rather large area (Campbell \& Stephensen, 1970, fig. 49D); presence of short, reduced, triangular trenches.

Hexaplax Doflein, 1904 (type species, by monotypy: Hexaplax megalops Doflein, 1904) differs from Holthuisea in having: dorsal carapace without lateral branchio-cardiac depressions; orbits large, extending on dorsal surface of carapace; eyes developed and with large and hammer-shaped cornea; supraorbital margin strongly sinuous; mxp3 with ischium expanded mesially; exposed portion of sternite 8 extremely small but visible dorsally; male abdomen narrow, somites 3-5 fused but with still distinct sutures; somite 6 narrow, hexagonal, with a marked lateral, subproximal expansion corresponding to the "button" of the locking mechanism (Doflein, 1904: 122, pl. 41 figs. 3, 4, pl. 50 fig. 7; Serène, 1964: 270, fig. 21, pl. 24 fig. A; Manning \& Holthuis, 1981: $168,171)$.

Hexapus, see above under fossil comparisons.

Lambdophallus Alcock, 1900 (type species, by monotypy: Lambdophallus sexpes Alcock, 1900) differs from Holthuisea in having: dorsal carapace with cervical and branchio-cardiac grooves and without lateral branchio-cardiac 
depressions; orbits small and circular; eyes reduced and fixed; male abdomen narrow, somites 1 and 2 free, somites 3-5 fused into a subhexagonal plate, with still visible sutures; somite 6 short, with markedly convex margins; presence of long, transverse trenches (Manning \& Holthuis, 1981: 169, 173, fig. 34).

Latohexapus Huang, Hsueh \& Ng, 2002 (type species, by original designation: L. granosus Huang, Hsueh \& Ng, 2002) differs from Holthuisea by many characters, including: carapace extremely wide; dorsal carapace regions well demarcated, separated by deep, smooth grooves, and coarsely tuberculated; eyes small; mxp3 with expanded ischium, narrow merus and wide propodus; thoracic sternum broad, sternites 4-7 granulate, sternite 8 dorsally visible as small, triangular plate, at least in the female; male abdomen proportionally narrow and diversely shaped, somites 3-5 fused, somite 6 hexagonal, with lateral expansion about at mid-length corresponding to the "button" of the locking mechanism; absence of stridulatory apparatus; presence of sternal trenches (Huang et al., 2002: 652, figs. 1b, 3, 4).

Paeduma Rathbun, 1897 (type species, by monotypy: Amorphopus cylindraceus Bell, 1859; preoccupied name, now Paeduma cylindraceum) differs from Holthuisea in having: front concave, depressed, more advanced laterally than medially; relatively shorter orbito-frontal width; exposed portion of sternite 8 distinctly visible dorsally; male abdomen much longer and narrower, somites 3-5 fused and forming distally-truncated triangle, somite 6 extremely long, as a linear plate, strongly constricted proximally; female abdomen longer, somite 6 more elongate (fig. 1E; Bell, 1859: 27-29, as Amorphopus; Guinot, 2006: 553-560, figs. 1, 2).

Parahexapus Balss, 1922 (type species, by monotypy: P. africanus Balss, 1922) differs from Holthuisea in having: carapace outline; dorsal surface with deep, complete cervical groove; orbits small but extending dorsally on carapace; eyes small; front broad; mxp3 more slender; reduced sternite 8 clearly visible dorsally; male abdomen narrow, somites 3-5 fused, with indistinct sutures, somite 6 and telson elongated; female abdomen with somite 1 narrow and high, somite 6 with anterior margin concave; absence of stridulatory apparatus (Monod, 1956: 370, figs. 494-496 as Hexapus (Parahexapus); Crosnier, 1967: 337, fig. 33 as Hexapus (Parahexapus); Manning \& Holthuis, 1981: 169, 175, fig. 36a-c).

Pseudohexapus Monod, 1956 (type species, by monotypy: Hexapus (Pseudohexapus) platydactylus Monod, 1956) differs from Holthuisea in having: carapace and lateral border outlines; dorsal surface without lateral branchiocardiac depressions; orbits extremely small; eyes reduced; exposed portion of 
sternite 8 small, visible dorsally; male abdomen narrow, somites 3-5 fused, with indistinct sutures and forming a plate with concave margins, somite 6 quadrate; absence of stridulatory apparatus (Monod, 1956: 365, figs. 478-493 as Hexapus (Pseudohexapus); Manning \& Holthuis, 1981: 169, 176, fig. 36df).

Spiroplax Manning \& Holthuis, 1981 (type species, by original designation: Thaumastoplax spiralis Barnard, 1950) differs from Holthuisea in having: carapace oval, narrower; dorsal surface with a faint branchio-cardiac groove and without lateral branchio-cardiac depressions; mxp 3 slender, propodus with mesial expansion distally; male abdomen triangular and regularly tapering, somites 3-5 fused without visible sutures and forming a plate with oblique margins; absence of stridulatory apparatus (at least apparatus not mentioned by the authors) (Barnard, 1950: 301, fig. 56h-1 as Thaumastoplax; Manning \& Holthuis, 1981: 169, 176, fig. 37; see also Pereyra Lago, 1988: 587).

Stevea Manning \& Holthuis, 1981 (type species, by original designation: Hexapus williamsi Glassell, 1938; holotype being a female) differs from Holthuisea in having: presence of cervical and branchio-cardiac grooves; curvature of the anterolateral border which passes below the exorbital angle; front with concave border and median protuberance; orbits shorter; eyes narrow, cylindrical; female abdomen narrow, with somites 2-6 fused but sutures still visible and not lined by two lateral pits, somite 5 with straight lateral margins, somite 6 elongated, narrow, subhexagonal (Glassell, 1938: 445, pl. 35 figs. 1-4; Manning \& Holthuis, 1981: 177, fig. 38; Guinot, 2006: 562, fig. 3) (fig. 1A-D).

Thaumastoplax Miers, 1881 (type species, by monotypy: T. anomalipes Miers, 1881) differs from Holthuisea in having: carapace widest in anterior half; lateral margin as raised tuberculate ridge; branchio-cardiac groove forming an H-shaped depression; orbits small; mxp3 slender, endopod recurved, with ischium and propodus expanded, merus narrow; exposed portion of sternite 8 small; male abdomen narrow, somites 3-5 fused, without visible sutures and forming a plate with concave anterior margins, somite 6 elongate and slender; absence of stridulatory apparatus; presence of long sternal trenches (Miers, 1881: 261, pl. 14 fig. 2; Monod, 1956: 363, figs. 471, 472 as Hexapus (Thaumastoplax); Manning \& Holthuis, 1981: 169, 177, fig. 39).

Tritoplax Manning \& Holthuis, 1981 (type species, by original designation: Hexapus stebbingi Barnard, 1947) shares with Holthuisea a rather similar carapace outline but differs by: branchio-cardiac groove forming an $\mathrm{H}$-shaped depression on dorsal surface; orbits less elongate, male abdomen narrower, 
somites 3-5 fused without visible sutures, somite 6 with concave borders, may be longitudinally divided; telson trilobate; absence of stridulatory apparatus; presence of short sternal trenches (Barnard, 1950: 299, fig. 56d-g as Hexapus stebbingi; Gordon, 1971: 109, fig. 3 as Hexapus (Hexapus) stebbingi; Manning \& Holthuis, 1981: 169, 180, fig. 40).

\section{GENERAL DISCUSSION}

The most closely related genus to Holthuisea gen. nov. is the living monotypic genus Stevea, the type species S. williamsi (Glassell, 1938) being known only from the eastern tropical Pacific thus far. The female holotype from San José, Guatemala, was found on a fine black sand and mud bottom, the sand being mixed with volcanic rock, at 18-20 (Glassell, 1938).

Holthuisea has been collected from volcaniclastic marls of middle Eocene age at "Albanello" quarry at Nogarole Vicentino (Vicenza, northeast Italy). In the same palaeoenvironment, numerous molluscs and echinoderms, as well as decapod crustaceans (palinurids, brachyurans, and stomatopods) have been found (De Angeli \& Garassino, 2006). Holthuisea is common at levels exposed at the "Albanello" quarry. Specimens occasionally preserving chelipeds and ambulatory legs, have been found with other uncommon hexapodids which have the characteristic thoracic sternum but display different body shapes: Holthuisea with wide and smooth carapaces; Eurohexapus De Angeli, Guinot \& Garassino, 2010, with subquadrate carapace, undulate dorsal surface, with regions defined by protuberances; Bellhexapus De Angeli, Guinot \& Garassino, 2010, with carapace wider than long and granular surface; and Eohexapus De Angeli, Guinot \& Garassino, 2010, with carapace wider than long, more enlarged anteriorly, with lateral margins diverging posteriorly and showing as granulate ridges.

The abdominal holding mechanism of the Hexapodidae shows different arrangements. In Hexaplax megalops, the abdominal margins of both sexes are coadapted with those of the sterno-abdominal cavity. The respective parts of both complement each other along several somites, and this results in a tightly locked abdomen, posteriorly to telson. In addition, there is on the edge of the sterno-abdominal cavity a "button" which corresponds to a lateral expansion of the external margin of the abdominal somite 6 and functions as a socket. This expansion is more or less pointed, and its location along the margin of the abdominal somite 6 is diverse. It varies from subproximal as in Holthuisea gen. nov. (figs. 3B, 4C), Bellhexapus (De Angeli et al., 2010, 
figs. 2C, D, 3B, non 3(2A), Eurohexapus (De Angeli et al., 2010, figs. 7C, D, 8E), Hexapus (Rathbun, 1910, fig. 36; Manning \& Holthuis, 1981, fig. 33b) and Tritoplax (Stephensen, 1946, fig. 53B, as Hexapus sexpes; Barnard, 1950, fig. 56e; Manning \& Holthuis, 1981, fig. 40a, d) to approximately midlength as in Hexapinus (Manning \& Holthuis, 1981, fig. 32c) and Latohexapus (Huang et al., 2008, figs. 3B, C, 4A, G). In Lambdophallus sexpes the laterally inflated subdistal portion of the short abdominal somite 6 probably corresponds to the location of the socket (Stephensen, 1946, fig. 52B; Manning \& Holthuis, 1981, fig. 34c). In other genera, such as Paeduma (fig. 1E; Guinot, 2006, figs. 1B, 2B, E) or Thaumastoplax (Manning \& Holthuis, 1981, fig. 39b), the location of the sternal "button" is not revealed by the shape of abdominal somite 6 . The holding system in Latohexapus granosus, well described by Huang et al. (2008: 656), shows some small differences but resembles the typical pressbutton mechanism (Guinot \& Bouchard 1998: 660), and probably functions in the same way.

The lateral expansion of abdominal somite 6 well visible in fossil hexapodid genera such as Holthuisea could represent a useful criterion for recognition of true hexapodids in the fossil record, implying that the locking system needs to be extensively studied in hexapodid taxa. In the Hexapodidae, the sternal "button" for the abdominal holding may persist in the adult (even ovigerous) females in the proximity of the vulvae (as in the female Paeduma examined), which is exceptional, albeit not unique, for Brachyura (Guinot \& Bouchard, 1998: 650, 660, fig. 17C, E; Guinot \& Quenette, 2005: 334, fig. 28).

\section{ACKNOWLEDGEMENTS}

We thank Viviana Frisone of the Museo Civico 'G. Zannato' of Montecchio Maggiore (Vicenza, Italy) who gave permission to study material housed there; Riccardo Alberti and Andrea Checchi of the "Associazione Amici del Museo Zannato" of Montecchio Maggiore who discovered and prepared specimens studied. Lawrence L. Lovell (Marine Biology Laboratory, County Sanitation Districts of Los Angeles, U.S.A.), asssisted by Don Cadien, repeatedly examined and commented on the holotype specimen of Stevea williamsi (deposited in the San Diego Museum of Natural History) and provided new photographs; the open abdomen photograph taken by Larry "on a hunch that it might be of some use" enabled us to determine correctly the sex of the Stevea williamsi holotype. Rafael Lemaitre (Department of Invertebrate Zoology, National Museum of Natural History, Smithsonian Institution, Suitland, MD, 
U.S.A.) kindly photographed a female specimen deposited in the USNM, erroneously referred to $S$. williamsi. We are greatly indebted to all of them. The assistance of Sylvain Charbonnier and Jean-Michel Pacaud (MNHN, "Département Histoire de la Terre"), who provided access to the Hexapodidae deposited in the palaeontological collection of the MNHN, Paris, is appreciated. Thanks are due to the "Département des Collections" of the MNHN for supporting a stay of Alessandro Garassino as invited researcher at the "Département Milieux et Peuplements aquatiques" of the MNHN in June 2009. We are greatly indebted to John W.M. Jagt (Natuurhistorisch Museum Maastricht, Maastricht, The Netherlands) for helpful comments on the manuscript and to P.K.L. Ng for valuable suggestions.

\section{REFERENCES}

BARNARD, K.H., 1950. Descriptive catalogue of South African decapod Crustacea. Annals of the South African Museum, 38: 1-837.

BELL, T., 1859. Description of a new genus of Crustacea, of the family Pinnotheridae; in which the fifth pair of legs are reduced to an almost imperceptible rudiment. Journal of the Proceedings of the Linnean Society of London (Zoology), 3: 27-29.

Beschin, C., A. Busulini, A. De Angeli \& G. Tessier, 1994. I Crostacei Eocenici della cava "Boschetto" di Nogarole Vicentino (Vicenza-Italia settentrionale). Lavori Società Veneziana di Scienze Naturali, 19: 159-215.

Beschin, C. \& A. De Angeli, 2004. Nuovi brachyuri eocenici dei Monti Lessini vicentini (Italia nordorientale). Studi e Ricerche - Associazione Amici del Museo - Museo Civico “G. Zannato", Montecchio Maggiore (Vicenza), 11: 13-22.

Beschin, C., A. De Angeli \& R. ZorZin, 2009. Crostaceai fossili del Veneto: una inedita fauna eocenica dei Lessini orientali (Monte Serea di San Giovanni Ilarione, Verona), con descrizione di tre nuove specie. Bollettino del Museo Civico di Storia Naturale di Verona, 33: $59-83$.

CAmpbell, B.M. \& W. Stephenson, 1970. The sublittoral Brachyura (Crustacea: Decapoda) of Moreton Bay. Memoirs of the Queensland Museum, 15(4): 235-301.

Crosnier, A., 1967. Remarques sur quelques Crustacés Décapodes benthiques ouestafricains. Description de Heteropanope acanthocarpus et Medaeus rectifrons. Bulletin du Muséum national d'Histoire naturelle, (2) 39(2): 320-344.

De Angeli, A. \& C. Beschin, 2001. I Crostacei fossili del territorio Vicentino. Natura Vicentina, 5: 5-54.

De Angeli, A. \& A. Garassino, 2006. Catalog and bibliography of the fossil Stomatopoda and Decapoda from Italy. Memorie della Società italiana di Scienze naturali e del Museo civico di Storia naturale di Milano, 35(1): 3-95.

De Angeli, A., D. Guinot \& A. Garassino, 2010. New hexapodid crabs from the Eocene of Vicenza (NE Italy) (Crustacea Decapoda, Brachyura, Hexapodidae). Atti della Società italiana di Scienze naturali e del Museo civico di Storia naturale in Milano, 151(1): 51-75.

De Grave, S., N.D. Pontcheff, S.T. Ahyong, T.-Y. Chan, K.A. Crandall, P.C. Dworschak, D.L. Felder, R.M. Feldmann, C.H.J.M. Fransen, L.Y.D. 
Goulding, R. Lemaitre, M.E.Y. Low, J.W. Martin, P.K.L. NG, C.E. Schweitzer, S.H. TAN, D. TShudy \& R. WetZer, 2009. A classification of living and fossil genera of decapod crustaceans. Raffles Bulletin of Zoology, (Supplement) 21: 1-109.

Doflein, F., 1904. Brachyura. In: Wissenschaftliche Ergebnisse der Deutschen TiefseeExpedition auf dem Dampfer "Valdivia", 1898-1899, 6: i-xiv, 1-314. (Gustav Fischer, Jena).

Glasell, S., 1938. New and obscure decapod Crustacea from the west American coasts. Transactions of the San Diego Society of Natural History, 8(33): 411-454.

Gordon, I., 1971. On the thoracic sternum in the subfamily Hexapodinae (Brachyura, Goneplacidae). Crustaceana, 21(1): 106-110.

Guinot, D., 1979. Données nouvelles sur la morphologie, la phylogenèse et la taxonomie des Crustacés Décapodes Brachyoures. Mémoires du Muséum national d'Histoire naturelle, (A) 112: 1-354.

— - 2006. Rediscovery of the holotype of Paeduma cylindraceum (Bell, 1859) and description of a new genus of Hexapodidae (Decapoda, Brachyura). Zoosystema, 28(2): 553-571.

Guinot, D. \& J.-M. Bouchard, 1998. Evolution of the abdominal holding systems of brachyuran crabs (Crustacea, Decapoda, Brachyura). Zoosystema, 20(4): 613-694.

Guinot, D. \& G. QuenetTe, 2005. The spermatheca in podotreme crabs (Crustacea, Decapoda, Brachyura, Podotremata) and its phylogenetic implications. Zoosystema, 27(2): 267-342.

HeNDRICKX, M.E., 1995. Checklist of brachyuran crabs (Crustacea: Decapoda) from the eastern tropical Pacific. Bulletin de 1'Institut Royal des Sciences naturelles de Belgique, Biologie, 65: 125-150.

HuANG, J.F., P.-W. HsueH \& P.K.L. NG, 2002. Crabs of the family Hexapodidae (Decapoda: Brachyura) from Taiwan, with description of a new genus and species. Journal of Crustacean Biology, 22(3): 651-660.

ICZN, 1999. International Code of Zoological Nomenclature. Fourth edition: i-xxix, 1-306. (The International Trust for Zoological Nomenclature, The Natural History Museum, London).

MANNING, R.B., 1982. A redescription of Cancer sexpes Fabricius, 1798 (Crustacea, Decapoda, Hexapodidae). Steenstrupia, 8(5): 157-161.

Manning, R.B. \& L.B. Holthuis, 1981. West African brachyuran crabs (Crustacea: Decapoda). Smithsonian Contributions to Zoology, 306: i-xii, 1-379.

MIERS, E.J., 1881. On a collection of Crustacea made by Baron Hermann-Maltzam [sic] at Goree Island, Senegambia. Annals and Magazine of Natural History, (5) 8(46): 259-281.

Monod, TH., 1956. Hippidea et Brachyura ouest-africains. Mémoires de l'Institut français d'Afrique Noire, 45: 1-674.

NG, P.K.L., D. Guinot \& P.J.F. Davie, 2008. Systema Brachyurorum: Part I. An annotated checklist of extant brachyuran crabs of the world. Raffles Bulletin of Zoology, (Supplement) 17: 1-286.

NybORG, T.G., 2002. Fossil decapod crustaceans from the early to middle Miocene Astoria Formation, Washington and Oregon, U.S.A: 1-224. (Unpublished M.S. Thesis, Kent State University, Kent, Ohio, (not seen)).

Pereyra Lago, R., 1988. Larval development of Spiroplax spiralis (Barnard, 1950) (Brachyura Hexapodidae) in the laboratory; the systematic position of the family on the basis of larval morphhology. Journal of Crustacean Biology, 8(4): 576-953. 
Rathbun, M.J., 1910. Brachyura. V. In: The Danish Expedition to Siam 1899-1900. Det Kongelige Danske Videnskabernes Selskabs, Skrifter 7. Raekke, Naturvidenskabelig og Mathematisk Afdeling, 5(4): 301-367.

SchweItZER, C.E., 2005. The genus Xanthilites Bell, 1858 and a new xanthoid family (Crustacea: Decapoda: Brachyura: Xanthoidea): new hypotheses on the origin of the Xanthoidea MacLeay, 1838. Journal of Paleontology, 79(2): 277-295.

Schweitzer, C.E. \& R.M. Feldmann, 2001. Differentiating fossil Hexapodidae Miers (Decapoda: Brachyura) from similar forms. Journal of Paleontology, 75: 330-345.

— — \& - 2005. Decapod crustaceans, the K/P event, and Palaeocene recovery: 17-53. In: S. Koeneman \& R.A. Jenner, (eds.), Crustacea and Arthropod relationships. (Taylor \& Francis Group, Boca Raton, London, New York, Singapore).

Schweitzer, C.E., R.M. Feldmann, A.B. Tucker \& R.E. Berglund, 2000. Eocene decapod Crustaceans from Pulali Point, Washington. Annals of Carnegie Museum, 69(1): 23-67.

SerÈnE, R., 1964. Goneplacidae et Pinnotheridae. In: Papers from Dr. Th. Mortensen's Pacific Expedition 1914-1916, 80. Videnskabelige Meddelelser fra Dansk naturhistorisk Forening i Kjøbenhavn, 126: 181-282.

StePhensen, K., 1946. The Brachyura of the Iranian Gulf, with an appendix: The male pleopods of the Brachyura. Danish Scientific Investigations in Iran [1945], 4: 57-237.

TESCH, J.J., 1918. The Decapoda Brachyura of the Siboga Expedition. I. Hymenosomidae, Retroplumidae, Ocypodidae, Grapsidae and Gecarcinidae. Siboga Expeditie, 39c(82): 1148.

First received 12 October 2009.

Final version accepted 17 December 2009. 